\title{
Exploring Pragmatic Identities of Teachers, Pupils and Parents in Chinese Primary School Online Education
}

\author{
Jue $\mathrm{Wu}$ \\ Changshu Institute of Technology, Suzhou, China \\ E-mail: likejackie@163.com
}

Received: April 5, 2021

Accepted: May 25, 2021

Published: June 17, 2021

doi:10.5296/ijl.v13i3.18605

URL: https://doi.org/10.5296/ijl.v13i3.18605

\begin{abstract}
The study of pragmatic identity has been a trend in the field of pragmatics. The primary schools in China have carried out online education in the spring of 2020 due to the outbreak of COVID-19, and this study focuses on two primary pupils and their teachers and parents, paying attention to the pragmatic identities constructed and the discursive devices used by the primary school teachers, pupils and their parents in this special online communication process. It is found that the teachers in this case study tend to construct four types of pragmatic identities in the online teaching activities, namely the knowledgeable scholars, instructional technicians, activity organizers and performance evaluators. The pupils participated in this study mainly build two types of pragmatic identities, namely the study explorers and atmosphere enliveners. The parents involved in the study tend to construct three pragmatic identities - teaching assistants, facility supporters and co-learners - in the online education context. Some discursive devices are used to construct these pragmatic identities, including the devices of language style, speech act, address, vocabulary selection and paralinguistic means. This study also yields some interesting findings on the interaction among teachers, pupils and parents during the process of identity construction in the online teaching and learning environment.
\end{abstract}

Keywords: Pragmatic identity, Discursive device, Chinese primary schools, Online education

\section{Introduction}

The control of the novel coronavirus pneumonia has been the top priority in the first season of 2020 in China. The education departments at all levels across the country, in line with the unified requirements of the Ministry of Education, have been fully committed to the prevention and control of the COVID-19 disease, and resolutely prevent the epidemic from 
spreading in schools. At the same time, the local education departments have also done a lot of work to promote the "online teaching and learning" in primary and secondary schools during the epidemic prevention and control period. The Ministry of Education has been coordinating and integrating the relevant teaching resources of the country, providing a variety of high-quality online teaching resources that can be selected and covered all over the country, and making every effort to ensure that teachers teach online and children learn online effectively.

Although distant or online teaching and learning has become more and more popular among colleges and universities in China, such a novel way of teaching and learning can seldom be seen in most of the public primary and secondary schools across the country. With all the schools, kindergartens, colleges, institutions and universities shut down because of the current epidemic, the teaching concepts and learning modes of the primary and secondary schools in China are having a series of big changes, and the identities of both teachers and students, even the parents of the students, are also undergoing big changes. Teachers use various online teaching platforms to teach at home, and students learn independently at home by watching videos or participating in live online courses. Some parents who "work from home" have also become a part of this special teaching process. Due to the unique characteristics of teaching modes and communication methods, network teaching and online learning is very different from traditional classroom teaching and learning, and the identity construction of teachers, students and even parents in online teaching activities will also be different from that in traditional classroom teaching and learning. Therefore, this study, focusing on the pragmatic identities of Chinese primary school teachers, pupils and parents in online courses, will explore their identity types and discourse construction strategies, aiming at further enriching and expanding the relevant research of pragmatic identity, promoting the development of identity research in online courses, and providing theoretical support and practical guidance for primary school online teaching and learning.

\section{Literature Review}

\subsection{Identity in Pragmatics}

Contemporary pragmatics research presents a trend of interdisciplinary and cross cutting. The issue of identity construction that traditional sociological psychologists pay attention to has become one of the hot spots in pragmatics research. At the 12th International Pragmatics Symposium, the research group of "Identity as Resources in Chinese Discourse" thought that the rapid development and highly hierarchical characteristics of Chinese society made the issue of identity a very sensitive factor affecting the content and way of discourse. Therefore, it is necessary to study the identity construction in the context of Chinese discourse.

The study of identity in pragmatics focuses on various types of identities of communicators, including national identity (Atkinson \& Kelly-Holmes, 2011), institutional and professional identity (Chiles, 2005; Rees \& Mourouxe, 2010), gender identity (Barnard, 2019; Eisenchlas, 2012) and personal identity (Carr, 2021; Drummond, 2021; Ho, 2010; Mogensen, 2021; Woike, 2020). With the development of the Pragmatic Identity Theory (Chen, 2018), the discussion of the pragmatic identity of communicators in various communicative contexts has 
become a research trend (e.g., Wang, 2016; Wu, 2019; Yuan, 2015).

It has been the default point of view in the field of linguistics that identity is constructed through discourse (Chen, 2013, 2018; de Fina, et al., 2006; Kroskrity, 2000). The study of identity and discourse mostly follows the view of social constructivism and pays attention to the dynamic construction of identity in speech interaction. The construction of identity from the perspective of pragmatics is also based on the theory of social constructivism, which holds that identity can be constructed through discourse and emphasizes the influence of context. The identity constructed through discourse can be regarded as a pragmatic resource to help the communicators achieve specific communicative purposes. According to Chen (2018), in the process of communication, in order to meet the specific needs of communication, communicators will make a variety of pragmatic efforts, which are manifested in the use of various pragmatic resources, and the identity of the communicators can be used as a part of pragmatic resources to facilitate the realization of their communicative needs. Other researchers (e.g., Hall, 1996; Grad \& Rojo, 2008) have also mentioned that identity is not something that people "own" or "have", but a resource that people "use" and "claim". Varieties of alternative identities in communication constitute a variety of pragmatic resources and provide a variety of choices for specific communication needs. In this sense, according to Chen $(2013,2018)$, the term of pragmatic identity means "a contextualized, intentional or unintentional self or other identity of the language user, and the other identities of the social individual or group mentioned by the communicator in the discourse."

\subsection{Pragmatic Identity and Discourse Practice}

It is a pragmatic process that the communicators choose or even create a specific identity from a number of identities in the context of specific communication, which is purposeful and dynamic. In a communicative event, in order to achieve a specific communicative purpose, the communicator can dynamically construct a variety of different identities with the development of the communication.

From Figure 1, it can be seen that in specific communication events, the communicators can extract different identities which can meet the different purposes according to different communication needs. The choices of the identities are reflected in the use of different discourses, so as to achieve different communicative effects. On the one hand, the construction of identities cannot be separated from the choices of discourse. The construction of pragmatic identities of communicators can be realized through a variety of discourse methods, including code, style, content, speech act, grammatical choice and other aspects (Chen, 2013). On the other hand, the different pragmatic identities constructed by the communicators can explain the selective use of various communicative discourses and reveal the deep motivation behind the choices of discourse, that is, in order to construct different identities to adapt to different contexts (Wu, 2019). 


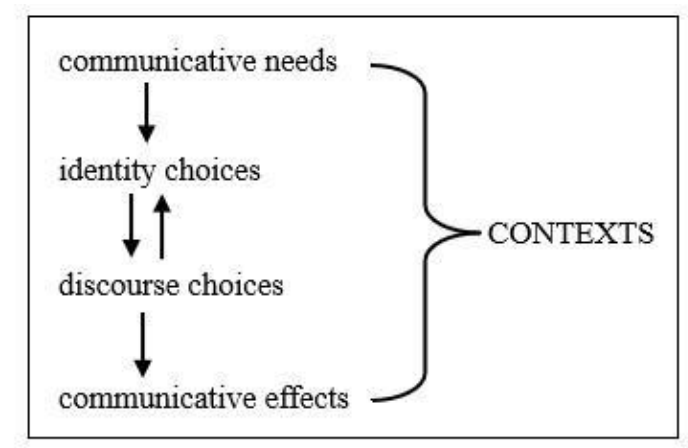

Figure 1. The dynamic choice of pragmatic identities (taken from Chen, 2013)

Pragmatists have pointed out that there is an interactive relationship between discourse and identity: the identity of the communicator will affect the discourse; meanwhile, the discourse chosen by the communicator will "shape" its corresponding identity (Chen, 2013). According to the theory of linguistic adaptation (Verschueren, 1999), the process of using language is the process of choosing language constantly. These choices can take place at all levels of language, such as vocabulary, clause, sentence, discourse, etc. The choices on these linguistic levels will help the communicators construct different identities. According to Tracy (2002), the speaker can not only use simple means such as personal direction, speech act, voice, category mixing, but also use more complex ways such as controlling interactive structure, directness (indirectness), narrative mode and stand to build different identities. Chen (2013) proposed that there are several types of discourse practice related to identity construction: code selection, style selection, discourse features, discourse content, discourse mode, speech act, address, grammar selection, vocabulary selection, phonetic features, and paralinguistic features (see Table 1).

Table 1. Types of discourse practice related to identity construction (taken from Chen, 2013)

\begin{tabular}{ll}
\hline $\begin{array}{l}\text { Discourse } \\
\text { Practice }\end{array}$ & Description \\
\hline Code selection & $\begin{array}{l}\text { Language (such as English, Chinese), dialect (such as Mandarin, } \\
\text { northeast dialect), specific language code, slang, etc. indicating } \\
\text { one's or the other's identity }\end{array}$ \\
\hline Style selection & $\begin{array}{l}\text { Language style indicates one's or the other's identity (such as } \\
\text { formal style, casual style, etc.) }\end{array}$ \\
\hline Discourse features & $\begin{array}{l}\text { Textual or conversational organizational features (such as turn } \\
\text { taking) that indicate one's or the other's identity }\end{array}$ \\
\hline Discourse content & $\begin{array}{l}\text { Discourse content (such as topic, information, viewpoint, } \\
\text { presupposition) that indicates one's or the other's identity }\end{array}$ \\
\hline Discourse mode & $\begin{array}{l}\text { Way of speaking that indicates the relationship between each } \\
\text { other's identities (the direct or indirect degree of expressing } \\
\text { ideas, the degree of engagement) }\end{array}$ \\
\hline Speech act & $\begin{array}{l}\text { Speech acts that indicate one's or the other's identity (e.g. } \\
\text { criticism, praise, suggestion, announcement) }\end{array}$ \\
\hline
\end{tabular}




\begin{tabular}{ll}
\hline Address & $\begin{array}{l}\text { Address terms indicating the identity of oneself, the other party } \\
\text { or others }\end{array}$ \\
\hline Grammar selection & $\begin{array}{l}\text { Grammatical features that indicate one's or the other's identity } \\
\text { (such as personal pronouns, tag questions, exclamations) }\end{array}$ \\
\hline Vocabulary selection & $\begin{array}{l}\text { Words (such as honorifics, jargon, abbreviations, modal } \\
\text { particles) that indicate one's identity or the relationship between } \\
\text { two parties }\end{array}$ \\
\hline Phonetic features & $\begin{array}{l}\text { Phonetic ways to indicate one's identity (pitch, speed, quality, } \\
\text { accent, standard tone, etc.) }\end{array}$ \\
\hline Paralinguistic features & $\begin{array}{l}\text { Gesture, distance, eye contact and other means that indicate } \\
\text { identity }\end{array}$ \\
\hline
\end{tabular}

According to the data collected in the current study, some types of discourse practice from the above table will be focused in the discussion of the following sections, namely, style selection, speech act, address, vocabulary selection and paralinguistic means. "Style selection" refers to the style which indicates one's or the other's identity, such as the formal style and the casual style. Language use has different levels of formality due to the differences in communication occasions. For example, daily conversation is not very formal, and classroom communication is much more formal. "Speech act" refers to some specific speech acts which can indicate one's or the other's identity. For example, in praise to his/her child, the speaker may indicate his/her identity as an encouraging parent. "Address" refers to some address terms indicating the identity of the communicators, such as "my dear friend", "Miss Wang" and so on. The former indicates that the speaker is a good friend to the listener, and the latter may drop a hint that the speaker is a student of the listener. "Vocabulary selection" means that the communicators may use different words (such as honorifics, jargon, abbreviations, modal particles) to indicate one's identity or the relationship between two parties. For instance, if the speaker uses a lot of financial terms in his/her daily conversation, it might indicate that he/she works in a bank or other financial institutions. Finally, "paralinguistic means" refers to the use of different non-linguistic means to indicate one's or the other's identity. Some non-verbal modes can help the communicators construct their identities more effectively. For example, a red heart painted next to the signature of a letter may indicate that the writer of the letter is a romantic lover of the receiver.

Although international scholars have studied the issue of identity from the perspective of pragmatics, the Pragmatic Identity Theory is the first one systematically constructed by Chinese scholars (Jiang, 2019). This theory has not only had specialized terms, but also defined the main research path of pragmatic identity theory, which has been proved to be effective in such research fields as second language teaching and learning practice (Li, 2010) and classroom teaching in general (Guo \& Jiang, 2020; Wu, 2015; Xu \& Chen, 2015). Therefore, the current study takes Pragmatic Identity Theory as a research model, trying to apply it to a more specific research field, that is, the online teaching and learning practice of primary schools in China. 


\subsection{Previous Studies on Pragmatic Identity in School Education}

Studies related to the teachers' identities in school education, especially in higher education, have not been rare (Liu \& Han, 2018; Silvestri et al, 2019; Zou, 2020, to name just a few). Teacher identity research is an essential part in the field of education, which is also one of the important factors that affect the professional development of teachers (Ajayi, 2011). Researchers have provided different definitions to teachers' identity from such perspectives as social responsibility (e.g., Farrell 2011) and identity construction (e.g., Guo \& Jiang, 2020). In terms of research content, most studies have focused on the construction process of teachers' professional identity (e.g., Tsui, 2007), and some paid attention to the dynamic analysis of teachers' multiple identities in class teaching context $\mathrm{Wu}, 2015 ; \mathrm{Xu} \& \mathrm{Chen}$, 2015).

In Xu \& Chen's study (2015), it has been found that identities constructed by college English teachers in classrooms include knowledgeable teachers, authoritative teachers, benign teachers and peer teachers. It has been argued that various physical, social and mental factors in communicative context constrain the construction of these identities. While in the online teaching context, which is quite different from the traditional classroom teaching environment, teachers may tend to construct some different identities due to different teaching contexts. For example, Wu (2015) has found that within different communication contexts, for distinctive communication aims, English teachers in online courses will employ different discursive strategies, such as the register, speech acts, address forms, and multimodality, to construct various pragmatic identities, namely educator, guide, organizer, participant, evaluator, material collector, and technician. These pragmatic identities and discursive strategies are diversified and dynamic, and can help teachers gain different communication effects in online teaching. Wang and Chen (2020) also find that Chinese university teachers in online lessons mainly construct three types of identities: professional identity, affective identity and technical identity, and these identities are constructed through different discursive practices, such as person-referencing practices and speech acts.

So far, most of the previous studies on identities in school education, no matter whether it is in traditional classroom teaching or in online teaching environment, have focused on the identities constructed by teachers, especially college teachers. Nevertheless, students are also a very important part in the process of school education, and an essential role in the context of class communication. Researching the identities constructed by students may further enrich the studies related to pragmatic identity in communication and point out a relatively new perspective of studying pragmatic identity in the field of school education. Furthermore, during the first season of the year of 2020, most primary schools in China have adopted a relatively unconventional education method, that is, the online teaching and learning mode, and many parents are even involved, which has made the communication between teachers, pupils and parents quite special. Unfortunately, few studies have paid attention to the pragmatic identities of teachers, pupils and even parents in the primary school online courses during such a special period in China. And the current research tries to touch upon this issue, hoping to bridge the gap and promote the studies in the related research field of pragmatic identity. 


\section{Research Method}

\subsection{Research Questions}

The above-mentioned relevant theories of discourse and identity construction from the perspective of pragmatics play an important guiding role in the current study, which focuses on the types of the pragmatic identities of primary school teachers, pupils and their parents, as well as the ways and strategies of their discourse construction in online teaching and learning. Based on the theoretical model proposed by Chen (2013), this paper will argue that in the special communicative context of online teaching and learning, in order to meet different communicative needs, primary school teachers, pupils and their parents tend to choose or create some different pragmatic identities, and the construction of these pragmatic identities is somewhat realized through different discursive devices, and finally different communicative effects are achieved.

Specifically speaking, the current paper will mainly answer the following questions:

1) What are some of the typical pragmatic identities constructed by primary school teachers, pupils and their parents in online courses? What discursive devices do they use to construct these pragmatic identities?

2) How do teachers, pupils and parents interact with each other in the construction of their pragmatic identities?

\subsection{Data Collection and Analysis}

There are mainly two modes of "homeschooling" during the COVID-19 outbreak, namely "organized massive online courses by famous teachers" (Mode A) and "autonomous live broadcast courses" (Mode B). As for the former, the education bureaus at all levels organize famous teachers to record teaching videos and broadcast them to the students of the whole province or city, who watch these videos and complete the homework assigned. And as for the latter mode, ordinary teachers at all levels broadcast live classes to their students through all kinds of social software and live stream applications, such as QQ, WeChat and DingTalk.

I have collected the data from the above-mentioned two online teaching modes in a city in east China's Jiangsu Province. I have focused on two primary school pupils, one is in Grade Three and the other is in Grade Six, and observed their performance as well as that of their teachers and parents during six weeks' "homeschooling" period (from February 10, 2020 to March 20, 2020). As for Mode A online courses, each of the two pupils took three classes in average every day, from Monday to Friday every week, accounting for a total of about 45 hours of "online course video watching". These subjects included Chinese, Math, English, Music, Arts, PE and Science. Besides watching those massive online course videos provided by famous teachers from all over the city, the two pupils would finish the homework assigned by their own school teachers every day, and discuss with them about their homework through some social software and communication applications, which took up about 2-4 hours every day. As for Mode B live classes, the teachers of the two pupils would have some live courses from time to time, in which the interaction between teachers and pupils was more dynamic 
than that in Mode A online courses.

I have observed the performance of the two pupils, their teachers as well as their parents in 20 online video classes (about 600 minutes of video watching and 1200 minutes of homework and discussion) and 4 live courses (about 240 minutes) which the two pupils have participated in. These video courses and live classes have all been randomly selected. Table 2 lists the detailed data information.

Table 2. Data of the current case study

\begin{tabular}{llll}
\hline Teaching modes & Mode A & & Mode B \\
\hline Activities & Video watching & Homework \& discussion & Live courses \\
\hline Length of time & 600 minutes & 1200 minutes & 240 minutes \\
\hline
\end{tabular}

In the following sections, I will discuss some of the typical pragmatic identities constructed by primary school teachers, pupils and parents in the special period of online teaching and learning, with a focus on the teachers' pragmatic identities as well as the discursive devices used in the construction of their identities. Due to the subjectivity of the researcher in judging and labelling the identity types, I conducted the evaluator validity test in the data analysis process. Two associated professors in the field of pragmatics were invited to judge the pragmatic identities constructed by the participants in 5 online video classes and 1 live course, which were randomly selected, and then the validity of the three evaluators, including me, the writer of this paper, was tested in order to minimize the impact on the research reliability caused by the writer's subjective factors.

What is worth mentioning is that the pragmatic identities found in this study are illustrative but not exclusive because of the relatively small dataset, and there is not a simple consistent one-to-one match between each pragmatic identity and the discursive device used by the participants. A certain type of pragmatic identity may be constructed by many kinds of discursive devices, and a certain discursive device may help the participant in building different types of pragmatic identities.

\section{Results and Discussion}

\subsection{Teachers' Pragmatic Identities: Types and Discursive Devices}

Traditionally, teachers are usually considered to play a major role of "educators" in the teaching practice, which can be regarded as the default identity of teachers. While in the online teaching and learning environment, primary school teachers in China tend to build some other pragmatic identities such as "knowledgeable scholars" and "instructional technicians". In the current case study, there are two online teaching modes - Mode A and Mode B as is mentioned in the previous section. In both of the two teaching modes, the primary school teachers tend to build or choose different pragmatic identities according to the different teaching contexts and communicative needs. In the following sections, I will discuss some of the types of the pragmatic identities and their discursive devices. What is worth mentioning is that the pragmatic identities discussed here, which are the typical ones emerging in both of the two teaching modes, are not exclusive but just descriptive, and the 
correlation between the pragmatic identities and discursive devices is not simply one-to-one equation. And this is also applied in the discussion of the pragmatic identities of primary school pupils and their parents.

\subsubsection{Knowledgeable Scholars and Instructional Technicians}

In Teaching Mode A, the 20 videos collected are provided by the municipal education bureau of the city. These videos cover such teaching subjects as Chinses, Math, English, Music, Arts, Science and PE. Altogether 16 teachers are involved in these videos. They are all famous teachers from across the city. They have been invited to record some teaching videos in advance, which are broadcast at a certain time to all the pupils in every primary school in the city. Different from the traditional classroom teaching, the video broadcast teaching is somewhat "teacher-centered". In the videos, the teachers mainly deliver some lectures and impart some important knowledge of the related subject to the pupils. There is little interaction between teachers and pupils. Pupils at home just watch the videos and take notes from time to time. In this special communicative context, the main communicative needs of the teachers are, first to impart knowledge to the pupils, and second to outline the learning path the pupils should follow. In order to meet these communicative needs, the teachers may construct two pragmatic identities, namely "knowledgeable scholars" and "instructional technicians".

Based on my observation, these teachers tend to construct their pragmatic identities of "knowledgeable scholars" and "instructional technicians" through some discursive devices. The first device is language style selection. The use of language has different degrees of formality due to the differences of communication occasions and contexts. For example, classroom communication is much more formal than ordinary daily conversation. Compared with the traditional classroom teaching, the communication discourse in the online teaching environment may be considered relatively informal. However, this does not mean that all the discourses that the online teachers use are informal. In Mode A teaching context in the current case, the teachers teach the pupils all kinds of knowledge in the way of video recording, during which process they would imagine that they are standing on the platforms in the classrooms and imparting the knowledge to their pupils. Therefore, the language style they choose is quite formal. For instance,

[1] 《元日》是北宋政治家王安石创作的一首七言绝句。这首诗描写新年元日热闹、欢 乐和万象更新的动人景象, 抒发了作者革新政治的思想感情, 充满欢快及积极向上的奋 发精神。

Yuanri is a seven-character quatrain written by Wang Anshi, a politician of the Northern Song Dynasty. This poem describes the new year's first day's lively, joyful and all-around renewal of the moving scene, expressing the author's ideological and emotional innovation of politics, full of cheerful and positive spirit of endeavor.

This example appears in a video recorded by a famous teacher who teaches Chinese to Grade Three pupils in primary schools. The teacher uses the formal style to provide pupils with the background and connotation of the poem Yuanri, or The First Day of the New Year. The use 
of such expressions as “七言绝句” “万象更新” “革新政治” and “积极向上”, as well as the complex sentence structure make the discourse sound academic and formal, which helps the teacher to construct the pragmatic identity of a "knowledgeable scholar".

After watching the recorded videos, pupils are normally asked to finish some homework assigned by their own teachers. The "ordinary" teachers usually assign and check their pupils' homework through some social software, such as QQ and WeChat. The pupils will usually take photos of their homework and submit them to their class chatting groups in the social software, and the teachers will check them and have further instruction and discussion with the pupils. In such a special communicative environment, the teachers may construct the pragmatic identity of "instructional technicians" by choosing the formal language style. For example,

\section{[2] 请同学们完成第 18 页的练习题, 并于今晚八点之前将做题情况提交至班级群。}

Please finish the exercises on page 18 and submit it to the class chatting group before 8:00pm.

[3] 鸡兔同笼是中国古代的数学名题之一。早在 1500 年前, 《孙子算经》中就记载了这 个有趣的问题: 今有雉兔同笼, 上有三十五头, 下有九十四足, 问雉兔各几何? 这四句 话的意思是：有若干只鸡兔同在一个笼子里, 从上面数, 有 35 个头, 从下面数, 有 94 只脚。问笼中各有多少只鸡和兔? 我们来总结一下这道题的解题思路: 如果先假设它们 全是鸡, 于是根据鸡兔的总数就可以算出在假设下共有几只脚, 把这样得到的脚数与题 中给出的脚数相比较, 看看差多少, 每差 2 只脚就说明有 1 只兔, 将所差的脚数除以 2 , 就可以算出共有多少只兔。

"Chickens and Rabbits in the Same Cage" is one of the famous mathematical problems in ancient China. As early as 1500 years ago, Sunzi Suanjing recorded this interesting problem: today there are pheasants and rabbits in the same cage, with 35 on the top and 94 feet at the bottom, and how many pheasants and rabbits in the same cage? These sentences in classical Chinese mean that there are several chickens and rabbits in the sage cage, and counting from the top, there are 35 heads, and from the bottom, there are 94 feet. How many chickens and rabbits are there in the cage? Let's now summarize the solution to this problem: if we assume that they are all chickens, then we can calculate the total number of feet under the assumption according to the total number of chickens and rabbits. Compare the number of feet obtained in this way with the number of feet given in the problem to see how much difference. Every two feet difference means that there is a rabbit. Divide the number of feet by two to calculate the total number of rabbits.

The above two examples are taken from the class chatting group of the six-grade pupil in the current case study. Her teacher assigns the homework in example [2] and explains the solution to the math puzzle in example [3]. It can be seen that the language style in these two examples is quite formal. For instance, the teacher uses some formal expressions like “请” “并” “于......之前” and “提交至” in example [2], and there is even a quotation from ancient Chinese works which emerges in classical written Chinese - “今有雉兔同笼, 上有三十五头, 下有九十四足, 问雉兔各几何” in example [3], and the teacher's explanation to this math 
problem also sounds academic and logical. By using such a formal language style, the teacher successfully constructs her pragmatic identity of an "instructional technician", directing her pupils the right way of solving math problems.

The second discursive device in constructing teachers' pragmatic identities in Mode A online teaching context is speech act. American philosopher-linguist John Searle (1969) classified illocutionary acts into five general types, namely representatives, directives, commissives, expressives and declarations. Each type has a common, general purpose. The current study mainly focuses on the speech act of directives in this teaching mode. In the teaching activities of online courses, teachers in this case study often put forward some directions or instructions to students, including direct instructions, mitigated instructions and indirect instructions. Let's look at some examples.

[4] 翻到第 23 页, 大声朗读该段落, 并尝试背诵。

Turn to page 23, read the passage aloud, and try to recite it.

[5] 同学们做好作业后, 要把详细的解题过程拍照上传到我们班级群的“作业”板块。有 同学反映说找不到“作业”板块, 就在“群应用”里, 大家再仔细找找。

Please take pictures of the detailed problem-solving process and upload them to the "homework" section of our class group. Some students said that they couldn't find the "homework" section. They were in the "group application" section. Please look for it carefully.

[6] 如有任何疑问, 请随时与我联系。

If you have any problems, please don't be hesitate to contact me.

[7] 还有一些同学没有提交作业, 马上就要截止了。

There are still a few children who haven't submitted their homework, and it's about to close.

Examples [4] and [5] are direct instructions, clearly telling pupils what to do and how to do during or after the online classes. Example [6] is a mitigated instruction. By using the politeness marker "please" and some mitigation measures ("if you have any problems"), the teacher reduces the force imposed on the recipient in the face threatening behavior (Brown \& Levinson, 1978/1987), showing a certain degree of politeness and respect to the pupils. In example [7], it seems that the teacher is stating a fact, but actually she is reminding or even warning some pupils to submit their homework before the deadline, which is an indirect instruction. Through using the speech act of directives, teachers in this case study have constructed their pragmatic identities of "instructional technicians" and achieved some certain communicative effects, that is, the pupils have been successfully guided and instructed in their online learning.

\subsubsection{Activity Organizers and Performance Evaluators}

I have observed four online live classes which the two pupils have participated in, each live class lasting about one hour. Altogether three teachers are involved in these live courses, 
teaching Chinese, Math and English respectively. A variety of teaching and learning activities are held in these live classes, including lecturing, asking and answering, game playing, group discussion, exercise doing, homework checking and so on. In these class activities, the teachers also construct the pragmatic identities of "knowledgeable scholars" and "instructional technicians", but some other identities, like "activity organizers" and "performance evaluators", are built or chosen more often. And these frequently-used pragmatic identities are also realized through some discursive devices.

Firstly, the language style device. In Mode B teaching activities, the teachers tend to use the informal style more often. Informal spoken language is simple and popular, which reminds people of friendliness, warmth and affinity (Zhao, 2011). The use of informal language style can make teachers' discourse more friendly and natural, and can shorten the distance between teachers and pupils. Here are some examples.

[8] 今儿个让我们来点轻松的。我来给大家讲个故事吧。从前有一个公主......

Today let's have some fun. I'm gonna tell you a story. Once upon a time, there was a princess ...

[9] 孩子们, 让我们烸起来! 来玩个好玩儿的游戏吧!

Come on boys and girls! Let's have fun in this interesting game!

[10] 准备好了吗? 一、二、二点五、三......冲呀!

Ready? One, two, two and a half, three ... go, go, go!

Such expressions as “今儿个” “烸起来” and “冲呀”in these examples are quite colloquial. The teachers take part in the class activities and organize the process of these activities. The pupils will feel that the teachers have become one of them participating together with them in every activity. It feels like chitchatting, and the pupils will not feel stressed in taking part in these activities. The class atmosphere is active and relaxed, and the pupils are more willingly to participate in the class activities. Through the use of the informal language style, the teachers in the current case study successfully build the pragmatic identities of "activity organizers" and achieve the communicative need, that is, to create a relaxed class atmosphere and make sure every class activity go smoothly in the online courses.

Secondly, the speech act device. In this teaching mode, I will focus on one of the five speech act types - expressives, which mainly express the speaker's feelings and attitudes towards a certain situation (Searle, 1969). For instance,

[11] 真是个很赞的想法！我非常同意你的观点!

Good idea! I can't agree with you more!

[12] 太有趣了! 我很喜欢你写的诗。

Very interesting! I like your poem very much.

[13] 你对这篇文章的理解很独到, 我非常欣赏。 
I really appreciate your special understanding toward this article.

[14] 你真聪明！干得漂亮!

You're brilliant! Well done!

[15] 你的解题思路是对的, 但是在解题方法上还可以更简化哦。

Your solution is right, but it can be more simplified.

The above examples are all expressives, which clearly express the teachers' attitudes, thoughts, feelings and emotions toward their pupils' performance in the class activities or homework. Example [11] is an approval from the teacher, examples [12] and [13] express the teachers' appreciation to the pupils' performance, example [14] is a praise, and example [15] shows the teacher's comments. The communicative need of the teachers is to tell the children what they think about their performance and let the children improve their study. With such a communicative need, the teachers in this case study use the speech act device of expressives to construct the pragmatic identity of "performance evaluators" and successfully achieve the communicative effect.

Thirdly, the address device. This device refers to the person deixis used by the speaker to address the addressee in language communication. Person deixis concerns the encoding of the role participants in the speech event in which the utterance in question is delivered (Levinson, 1983). Because this research involves the address between teachers and pupils, I will mainly focus on one sub-category of the person deixis - the social deixis used by teachers in online teaching activities. The social deixis here takes its broad sense, including personal pronouns (e.g., "I" "you"), social address (e.g., "Mr." "Miss"), titles (e.g., "Dr." "Professor"), relational address (e.g., "classmates" "my friends"), name address (e.g., "Mary") and intimate address (e.g., "honey"). In the online live classes, the teachers tend to use different ways of address to construct their pragmatic identities. The following are some examples.

[16] 顾阳，请你来回答一下这个问题，谢谢！

Gu Yang, please answer this question. Thanks a lot!

[17] 我们已经学到了这么多有用的知识, 我太高兴了!

I'm glad to see that we've learned so much useful knowledge!

[18] My dear friends, welcome to our English Fun Club! Hope you'll have a wonderful time here!

In example [16], the teacher calls a pupil by his name, which shows a certain authority of teachers. This will facilitate the teacher in organizing the class activities, thus helping the teacher to build the pragmatic identity of an "activity organizer". In example [17], the teacher uses the first person singular "I" to refer to herself, and the first person plural "we" to refer to her pupils. There are two ways to use the first person pronoun "we": inclusive use and exclusive use. In this case, the use of "we" refers to the exclusive use, which actually refers to the addressees - the pupils. This kind of exclusive use of "we" helps the teacher to effectively 
integrate into the pupils' class activities, which sounds very kind and natural. In example [18], the English teacher calls her pupils "my dear friends", which can effectively shorten the distance between the teacher and the children, so that class communication can be carried out in a harmonious atmosphere. From the above examples, we can see that the teachers tend to construct the pragmatic identity of "activity organizers" through the use of the address device, which helps them to satisfy their communicative need of organizing all kinds of class activities and making them go smoothly. And the choice of this pragmatic identity also achieves a certain communicative effect, that is, the pupils are encouraged to take part in the class activities and finally learn some useful knowledge and skills.

Till now I have discussed some of the pragmatic identities constructed by teachers in both Mode A and Mode B teaching and learning contexts in the current case study. I have focused on four pragmatic identities which are built or chosen frequently in this case, namely the "knowledgeable scholars", "instructional technicians", "activity organizers" and "performance evaluators". Of course, there are also some other pragmatic identities in the online teaching context, for instance, the "information collectors" and "network technicians", but I will not discuss them because they are not the most typical ones used by the teachers in this case study. The above-mentioned typical and frequently-used pragmatic identities are constructed by the teachers through some discursive devices, including language style, speech act and address. These discursive devices may help the teachers to build various pragmatic identities according to the different communicative needs and achieve the different communicative effects in the online teaching and learning activities.

\subsection{Pupils'Pragmatic Identities: Types and Discursive Devices}

Traditionally, primary school pupils in China are used to receiving education in schools. A typical class normally consists of 30-50 pupils. They study together, have classes together, play games together, and do most of the learning activities together at the same time and in the same place. However, during the period of the COVID-19 outbreak, almost all the schools are closed and the pupils have to stay at home to have classes. In some families, the parents have to work outside, and the children must take online courses all by themselves; while in some other families, the parents work from home, and the children will have online classes under the supervision of their parents. Compared with the situation in schools, "homeschooling" has much higher requirements on the children's self-learning abilities. They have to watch the teaching videos by themselves, take notes by themselves, do homework by themselves and actively take part in the other online teaching and learning activities. In the traditional classrooms, pupils are considered to be more passive "knowledge receivers", whose major tasks are listening to teachers' orders and finishing various assignments. However, in the online learning environment, the pupils may become more active learners, who tend to construct some pragmatic identities different from their traditional and default identity of "passive learners". In this section, I will discuss some typical pragmatic identities built or selected by the pupils in the process of online learning in the current case study.

\subsubsection{Study Explorers}

The first one is "study explorers". The pupils are encouraged and guided by their teachers to 
do various tasks in the online teaching and learning activities. In order to finish the assignments given by their teachers, the pupils have to search the Internet to find some information and learning materials related to their study. They learn to form their own ideas and thoughts after exploring those materials. And they have to report their discoveries to their teachers and classmates online. In these processes, the pupils act like "study explorers" surfing in the ocean of knowledge. Some discursive devices may help them in constructing this pragmatic identity. For example,

[19] 读了匹诺曹的故事, 我懂得了爱能够给予人们新生, 爱能够给予人们阳光, 爱能 够给予人们无限的幸福。

After reading the story of Pinocchio, I have realized that love can give people a new life, love can give people sunshine, and love can give people infinite happiness.

[20] 我有几个背英语单词的好方法, 分享给大家: 首先是读音记忆, 根据字母组合、 读音规则进行记忆, 会读一个单词, 便会拼写出来。其次是拆拼记忆, 把一个生词分成 两个或两个以上的单词, 或分成一个已经认识的单词和另外一个或几个字母来记忆。最 后是睡眠记忆, 晚上睡前读两遍要记的单词, 然后睡觉, 第二天醒来后再读两遍, 这样 记忆效果很不错。

I have a few good ways to memorize English words. I'd like to share them with you. First of all, I can memorize the words according to the combination of letters and pronunciation rules. If you can read a word, you can spell it out. The second is to separate a new word into two or more words, or into a known word and several other letters. The last is called sleep memory. Read the words twice before going to bed at night, then go to sleep, and then read them twice after waking up the next morning. This has very good effect.

The relatively formal language style in these pupils' discourses, which mainly appears in the form of the parallel structure “爱能够给予人们......” in example [19] and the logical connection words “首先” “其次” and “最后” in example [20], indicates that they have followed the teachers' instruction, searched some related information, and finally had their own ideas about the learning materials. In order to satisfy their communicative need, that is, to show their diligence and earnestness in study to their teachers, they use the discursive device of a formal language style, which helps them to construct the pragmatic identity of "study explorers".

\subsubsection{Atmosphere Enliveners}

The second pragmatic identity which is most frequently built by the pupils in this case study is "atmosphere enliveners". In the online live classes, the teachers and pupils can communicate with each other through distant conversations. They can "talk" to each other by sending voice messages, typing words, sending emoticons and other technical ways. Sometimes in an online live course, when the teacher asks a question, there may be no response from the pupils on the other side of the computer, which is quite awkward for the teacher. Active responses from pupils can enliven the class atmosphere and further promote the smooth development of the class. The pupils in this case study have played this role very well by giving active responses and interacting with their teachers frequently and effectively. 
Through this interaction, the pupils tend to construct the pragmatic identity of "atmosphere enliveners", and this pragmatic identity is realized, to a large degree, with the help of the discursive device of paralinguistic means.

In the teaching activities of online courses, besides language mode, we should also consider the influence of non-verbal mode on the identity construction of the communicators, because "non-verbal mode can highlight the information or meaning conveyed by language mode" (Chen \& Qian, 2011: 90). In the online communication, such non-verbal modes as font, size, figure, image, color, emoticon and so on are often combined with the language mode, so as to achieve the communication effect that is not easily achieved in general communication. For instance, the pupils like sending some emoticons to their teachers to express their feelings and attitudes in the online classes. The emoticon "^_^" indicates that the pupil likes what the teacher has said, and the emoticon of a red rose expresses the pupil's respect for and gratitude to the teacher. Here are some other examples:

\section{[21] 我懂啦, 谢谢赵老师！}

I understand. Thank you, Miss Zhao!

[22] 这道题好难啊! 记有没有谁来教教我?

This is so difficult! Is there anyone who can help me?

\section{[23] 哇！李子涵回答得好棒啊！}

Wow! Li Zihan answered this question very well!

The above examples are taken from the class chatting groups of the two pupils participated in this case study. The emoticon of a heart made of many red roses in example [21] shows the gratitude of the pupil to the teacher; the emoticon of a crying bear in example [22] indicates that the pupil feels it very disappointing to solve the problem; and the emoticon of a smiling face with a thumb up in example [23] expresses the pupil's appreciation and admiration to his classmate. The emoticons used in these discourses may encourage the other pupils in the same class to make active responses and help the teacher with the ongoing of the online teaching activities, which makes the class atmosphere more active and relaxed.

To sum up, in the online classes, in order to satisfy different communicative needs and achieve different communicative effects, pupils may construct some pragmatic identities, among which the "study explorers" and the "atmosphere enliveners" are the most typical and frequently selected ones. The pupils will use some discursive devices, such as language style and paralinguistic means, to build the pragmatic identities. 


\subsection{Parents' Pragmatic Identities: Types and Discursive Devices}

Under normal circumstances, the majority of working parents will not be homeschooling their children to the extent that they are having to do in the current epidemic outbreak. With almost all the educational institutions from kindergartens up to universities being closed, many working parents are under pressure to both deliver what their employers are expecting and support their children to stay on track with their education. There is usually quite low involvement of parents in the traditional classroom teaching and learning environment, but during this special period of online teaching and learning, many parents are involved, no matter whether they are willingly or not.

The parents of the two pupils in this case study have worked from home during the epidemic period. Based on my observation, these parents build some pragmatic identities in their children's online learning activities, and the most typical and special ones are "teaching assistants", "facility supporters" and "co-learners".

\subsubsection{Teaching Assistants}

As for the first one, the "teaching assistants", the parents may use the discursive devices of formal language style and speech act. For instance,

[24] 晚上好, 龚老师! 我已经检查了我孩子的作业, 并按照您的指示提交到了班级群。 如果您发现有任何错误, 请及时与我联系。非常感谢!

Good evening, Miss Gong! I have checked my kid's homework and submitted it to the class chatting group according to your instruction. Please don't be hesitate to contact me if you find some mistakes. Thank you very much!

[25] 明明, 你有没有完成今天的作业了? 我刚检查了你的数学作业, 发现了一个错误。 过来, 我给你讲解一下, 我们一起来完成这道题。

Mingming, have you finished all the homework today? I've just checked your math assignment and found a mistake in this problem. Come here and I'll explain it to you. Let's work together to solve it.

In example [24], the parent communicates with the teacher in a much formal language style. She has assisted the teacher in doing some learning-related activities, such as checking the child's homework and submitting it to the online discussion group. By using the formal language style, the parent successfully constructs her pragmatic identity of a "teaching assistant" and achieves a certain communicative effect. In example [25], the parent uses the speech act of directives to help her child with his study, and these directives promote the construction of her pragmatic identity of a "teaching assistant".

\subsubsection{Facility Supporters}

The second pragmatic identity of parents who are involved in the online classes is "facility supporters". The biggest difference of the online teaching from the traditional classroom teaching is the high requirement on the "online" facilities. A variety of facilities are needed in the online teaching and learning activities, such as computers, notebooks, tablets, mobile 
phones and other network facilities. More often, these facilities are not in a satisfied condition. Let's look at the following conversation between a daughter and her father.

[26] 女儿: 爸爸, 过来一下! 我的电脑不行了, 我看不见老师啦!

爸爸: 等一会儿啊, 让我看一眼。(几分钟后) 解决了! 能看见老师吗?

女儿：看见啦！哇, 太棒了！你是怎么修好的呀?

爸爸：这个简单，只要 IP 地址和 DNS 地址都设置为“自动获取”并保存就可以了。

Daughter: Dad, come here! My computer doesn't work. I can't see the teacher anymore.

Dad: Wait a minute. Let me have a look. (several minutes later) Here we go! Can you see your teacher?

Daughter: Yes! Wow, it's great! How did you do that?

Dad: Simple. I've set both IP address and DNS address to "obtain automatically" and saved it.

In the above conversation, the parent uses some technical terms such as "IP address" and "DNS address", and this discursive device of vocabulary selection helps him to build a pragmatic identity of a "facility supporter".

\subsubsection{Co-learners}

The third pragmatic identity created by the parents working from home and homeschooling their children is "co-learners". The parents in this case study will watch the recorded teaching videos together with their children, supervise them in homework doing and discussing with them some study issues. In these processes, the parents are actually studying together with the children and they can be regarded as "co-learners" of the pupils who take online courses. In the communication with their children, the parents will use such discursive devices as informal language style, the speech act of expressives and the address of personal deixis in the construction of the pragmatic identity of "co-learners". The following conversation, taking place between a mother and her son, is about the child's English lessons.

[27] 妈妈: 明明啊, 咱们一起来听课。老师讲的这个我不是很懂哎。

儿子: 好的, 妈妈, 我来解释一下啊。看这幅图, 这个男孩在教室里干嘛呀?

妈妈：他正在飞奔。

儿子：那他在教室里跑这么快，这么做对不对呢？

妈妈：我觉得在这么一个小空间内跑这么快会很危险的, 对吧? 我懂啦!

儿子：所以我们应该对他说“Please don't run in the classroom.”

妈妈：哇，你真棒！我也学到了很多哦。

Mum: Mingming, I'm gonna take this class together with you. I just can't understand this. 
Son: Ok, Mum, let me explain it to you. Just look at this picture. What's the boy doing in the classroom?

Mum: He's running very fast.

Son: Is it right for him to do so?

Mum: I think it's very dangerous to run so fast in such a small room, right? Gotcha!

Son: So we should say to him, "Please don't run in the classroom."

Mum: Wow, good for you! I've learnt a lot.

In summary, for some parents who work from home and are involved in their children's online learning activities, the discursive devices of style selection, speech act selection, vocabulary selection and address selection may help them in building or choosing some special pragmatic identities, namely the "teaching assistants", "facility supporters" and "co-learners". The selection of these pragmatic identities is aimed at satisfying different communicative needs, and finally helps the parents in achieving the communicative effects they want.

\subsection{The Interaction in the Construction of Pragmatic Identities}

During the six weeks' online education, the teachers, pupils and parents in the current case study have constructed a variety of pragmatic identities through the use of different discursive devices. Table 3 is a summary of some of the typical pragmatic identities as well as their discursive devices.

It has been found in the current case study that primary school teachers tend to use such discursive devices as language style, speech act and address to construct the pragmatic identities of knowledgeable scholars, instructional technicians, activity organizers and performance evaluators. Pupils tend to build the pragmatic identities of study explorers and atmosphere enliveners via the use of language style and paralinguistic means. By applying to such discursive devices as language style, speech act, vocabulary and address, the parents in this case study tend to create some special pragmatic identities, like teaching assistants, facility supporters and co-learners. The pragmatic identities mentioned here are not the only ones that may emerge in the online teaching and learning practice in primary schools, but the typical ones which are used more frequently by the participants in this case study. Moreover, the discursive devices discussed here are also not exclusive, and there is not a simple one-to-one correlation between each pragmatic identity and discursive device. A participant may use different kinds of discursive devices to build various types of pragmatic identities.

Table 3. Pragmatic identities and discursive devices found in the case study

\begin{tabular}{lll}
\hline & Pragmatic identities & Discursive devices \\
\hline Teachers & knowledgeable scholars & language style \\
& instructional technicians & speech act \\
& activity organizers & address \\
performance evaluators & \\
\hline
\end{tabular}




\begin{tabular}{lll}
\hline Pupils & study explorers & language style \\
& atmosphere enliveners & paralinguistic means \\
\hline Parents & teaching assistants & language style \\
& facility supporters & speech act \\
& co-learners & vocabulary \\
& & address \\
\hline
\end{tabular}

As is shown in Figure 1 in the previous section, there is an interactive relationship between discourse and identity. The identity of the communicator will affect the discourse, and at the same time the discourse chosen by the communicator will build its corresponding identity (Chen, 2013). This has been further proved by the findings of the current case study. Figure 2 shows a detailed interaction between pragmatic identity and discourse in primary school online education, which can be regarded as an application of Chen's model (2013) in a specific communication context.

Specifically speaking, the pragmatic identities of the participants in this case study will affect their discourse that is, the different types of pragmatic identities may be manifested via the use of different discursive devices. Meanwhile, the discourse chosen by the participants will help them in constructing various pragmatic identities. And in this process, the communication needs and effects cannot be neglected. For instance, the communicative need of a teacher in the online teaching practice may be to teach his/her pupils some knowledge and skills, so in order to meet this communicative need, the teacher may use the discursive device of a formal language style to construct the pragmatic identity of a knowledgeable scholar, and by building such an identity, the teacher may successfully impart some important knowledge to his/her pupils, which is the communicative effect of the whole communication process.

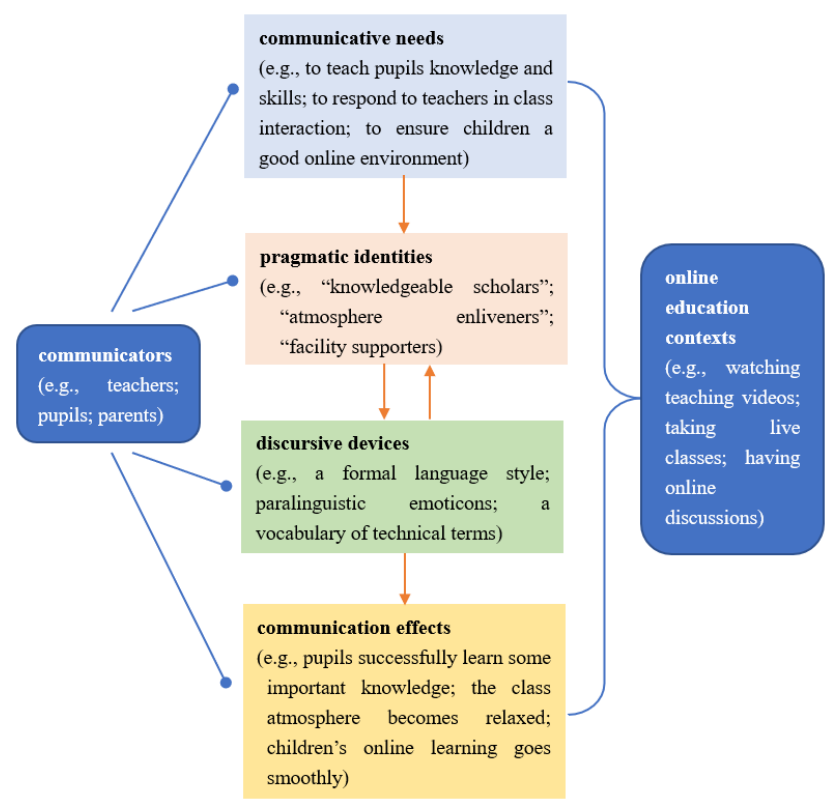

Figure 2. The interaction in the construction of pragmatic identities in primary school online education 


\section{Macrothink}

International Journal of Linguistics

ISSN 1948-5425

2021, Vol. 13, No. 3

Furthermore, besides the interaction between pragmatic identity and discourse, Figure 2 also shows that there is an interaction among the three parties involved in the construction of their pragmatic identities. The building of a certain type of pragmatic identity of one party may become a new context in the communication and trigger the construction of a type of pragmatic identity of another party. The following conversation is taken from the chatting record of a pupil's class chatting group.

[28] 老师: 今天的作业是做一份有关“垃圾分类” 的英语手抄报, 做好后拍照上传到班级 群的“作业”板块，下星期二截止。

学生 1：好的范老师, 知道了, 我会认真完成的

学生 2: 范老师, 可以在网上找资料吗?

老师：可以的，网上有很多相关资料。

学生 3: 范老师，我没有手机，不会上传啊

老师：同学们只要完成手抄报就可以了，上传的工作麻烦请家长们做一下。

家长 1：收到。

家长 2: 收到。

家长 3：收到，做好后马上传，谢谢老师！

Teacher: Today's homework is to do an English handwritten newspaper about "garbage sorting". After doing it, take a picture and upload it to the "homework" section of the class group. It will be closed next Tuesday.

Pupil 1: OK, Miss Fan, I know, and I will do it carefully

Pupil 2: Miss Fan, can I look for some information from the Internet?

Teacher: Yes, of course. There's a lot of relative information on the Internet.

Pupil 3: Miss Fan, I don't have a mobile phone, so I can't upload it

Teacher: Pupils, you only have to finish the handwritten newspaper. And you can ask your parents to upload the pictures for you.

Parent 1: Got it.

Parent 2: Got it.

Parent 3: Got it. I'll upload it as soon as my kid finishes it. Thank you!

In the above example, the three parties, namely the teacher, the pupils and the parents are having some online discussion. By using the formal language style, the teacher first constructs a pragmatic identity of "an instructional technician", assigning the homework and 
directing the pupils how to finish the homework. This creates a specific communication context, in which the pupils' and parents' communicative need is to respond to the teacher. By using some emoticons, Pupil 1 and Pupil 3 activate their pragmatic identity of "atmosphere enliveners"; by using a relatively more formal language style in asking the teacher about the way of finishing the homework, Pupil 2 builds his pragmatic identity of "a study explorer". When Pupil 3 proposes a difficulty, the teacher tends to realize that this may be a common problem for the whole class, so she continues to use her pragmatic identity of "an instructional technician", directing the parents how to help their children to finish the homework. And this building of the pragmatic identity further triggers a new communication context, in which the parents activate their pragmatic identities of "teaching assistants" and "facility supporters", providing some technical support and helping their children to complete the homework. Therefore, the three parties involved in this special online communication are interacting with each other, dynamically constructing or activating various types of pragmatic identities according to different contexts, which are also created dynamically during the whole communication process. The dynamic interaction among the three parties involved in the current case study may be considered as an application and enrichment of Chen's model (2013), making it more insightful and comprehensive.

\section{Conclusion}

So far, we have discussed some of the types as well as the discursive devices of pragmatic identities constructed by primary school teachers, pupils and parents in online teaching and learning practice. It has been found that teachers tend to frequently use four types of pragmatic identities, namely the knowledgeable scholars, instructional technicians, activity organizers and performance evaluators. Pupils in this case study mainly build two types of pragmatic identities during the process of online learning - study explorers and atmosphere enliveners. Some parents who work from home are also involved in this special period of online education, and they tend to mainly construct three pragmatic identities, namely teaching assistants, facility supporters and co-learners, which are quite different from their traditional identities. What is worth mentioning is that the pragmatic identities discussed in the current study are not the only ones constructed by the teachers, pupils and parents, and are not limited in the context of the online education. Teachers, for example, may also use the pragmatic identity of "knowledgeable scholars" in the traditional classroom teaching, and pupils may also "enliven" the class atmosphere by responding to their teachers actively in the traditional classrooms. However, the above-mentioned pragmatic identities of teachers, pupils and parents are the most typical and frequently-used ones in this special period of online education, and the construction of them is via the use of some discursive devices with some online characteristics. During the communication process, the three parties - teachers, pupils and parents - may interact with each other according to the different communicative needs, and build or activate different pragmatic identities dynamically. In order to satisfy different communicative needs, the teachers, pupils and parents in this study tend to choose different discursive devices to construct various pragmatic identities, and the choices of these pragmatic identities as well as the discursive devices may help the communicators achieve some certain communication effects in the specific context of online teaching and learning. 


\section{Macrothink}

International Journal of Linguistics

ISSN 1948-5425

2021, Vol. 13, No. 3

The current research is a tentative exploration of the pragmatic identities in Chinese primary school online education. Due to the relatively small dataset, the results of this study may not be applicable to all the primary schools in China. But it points out a feasible research direction for the researchers in the field of pragmatics, the field of distant education and the field of primary school online teaching and learning. The future studies may build a larger dataset and focus on the pragmatic identities of teachers, students and parents involved in online teaching and learning practice in secondary schools or universities and colleges across China and even the whole world.

\section{References}

Ajayi, L. (2011). How ESL teachers' sociocultural identities mediate their teacher role identities in a diverse urban school setting. The Urban Review, 43, 654-680.

Atkinson, D., \& Kelly-Holmes, H. (2011). Code switching, identity and ownership in Irish radio comedy. Journal of Pragmatics, 43(1), 251-260. https://doi.org/10.1016/j.pragma.2010.07.021

Barnard, A. (2019). Developing Researcherhood: Identity tensions and identity work of women academics reflecting on their researcher identity. Forum: Qualitative Social Research, 20(3), 1-22. http://doi.org/10.17169/fqs-20.3.3238

Brown, P., \& Levinson, S. C. (1978/1987). Politeness: Some universals in language use. London: Cambridge University Press.

Carr, D. (2021). Personal identity is social identity. Phenomenology and the Cognitive Sciences, 20(2), 341-351.

Chen, X. R. (2013). Pragmatic identity: Dynamic choice and discursive construction. Foreign Languages Research, 4, 27-32. http://doi.org/10.13978/j.cnki.wyyj.2013.04.009

Chen, X. R. (2018). Pragmatic identity: How to do things with words. Beijing: Beijing Normal University Press.

Chen, X. R., \& Qian, Y. H. (2011). The application of multimodal analysis in pragmatics. Foreign Languages in China, 89-93. http://doi.org/10.13564/j.cnki.issn.1672-9382.2011.05.007

Chiles, T. (2005). The construction of an identity as "mentor" in white collar and academic workplaces: A preliminary analysis. Journal of Pragmatics, 39(4), 730-741. https://doi.org/10.1016/j.pragma.2006.11.015

De Fina, A., Schiffrin, D., \& Bamberg, M. (2006). Discourse and identity. Cambridge: Cambridge University Press.

Drummond, J. (2021). Self-identity and personal identity. Phenomenology and the Cognitive Sciences, 20(2), 235-247.

Eisenchlas, S. A. (2012). Gendered discursive practices on-line. Journal of Pragmatics, 44(4), 335-345. https://doi.org/10.1016/j.pragma.2012.02.001 


\section{Macrothink}

International Journal of Linguistics

ISSN 1948-5425

2021, Vol. 13, No. 3

Farrell, T. S. C. (2011). Exploring the professional role identities of experienced ESL teachers through reflective practice. System, 39, 54-62.

Grad, H., \& Rojo, L. (2008). Identities in discourse: An integrative view. In R. Dolon, \& J. Todoli (Eds.), Analysing identities in discourse (pp. 3-28). Amsterdam: John.

Guo, Y. T., \& Jiang, Y. (2020). A case study of English teachers' discursive construction of pragmatic identities. Foreign Language Education in China, 3(1), 68-76.

Hall, J. K. (1996). Who need "identity"?. In S. Hall, \& P. du Gay (Eds.), Questions of cultural identity (pp. 1-17). London: Sage.

Ho, V. (2010). Constructing identities through request e-mail discourse. Journal of Pragmatics, 42(8), 2253-2261. https://doi.org/10.1016/j.pragma.2010.02.002

Jiang, Q. S. (2019). Studies of pragmatic identity in the last decade: five theoretical approaches and methodologies. Journal of Fujian Normal University (Philosophy and Social Sciences Edition), (1), 57-63. https://doi.org/10.12046/j.issn.1000-5285.2019.01.008

Kroskrity, P. (1999). Identity. Journal of Linguistic Anthropology, 9(1-2), 111-114. https://doi.org/10.1525/jlin.1999.9.1-2.111

Levinson, S. C. (1983). Pragmatics. Cambridge: Cambridge University Press.

Li. C. T. (2010). Identity theory and ecological pedagogy in L2 learning context. Journal of Guangdong University of Foreign Studies, (6), 101-103.

Liu, Z., \& Han, C. H. (2018). Construction and discussion of online course resources under the background of "Internet plus". China Adult Education, 23, 85-88.

Mogensen, A. L. (2021). Is identity illusory?. European Journal of Philosophy, 29(1), 55-73.

Rees, C. E., \& Monrouxe, L. V. (2010). "I should be lucky ha ha ha ha": The construction of power, identity and gender through laughter within medical workplace learning encounters. Journal of Pragmatics, 42(12), 3384-3399. https://doi.org/10.1016/j.pragma.2010.05.004

Searle, J. (1969). Speech acts: An essay in the philosophy of language. London: Cambridge University Press.

Silvestri, K. N., McVee, M. B., Jarmark, C. J., Shanahan, L. E., Pytlak-Surdyke, M., \& English, K. (2019). Teacher identity in an after-school engineering club: navigating border crossing in an unfamiliar community of practice. The Primary School Journal, 120(1), 1-31. https://doi.org/10.1086/704542

Tracy, K. (2002). Everyday talk: Building and reflecting identities. New York: Guiford Press.

Tsui, A. B. M. (2007). Complexities of identity formation: A narrative inquiry of an EFL teacher. TESOL Quarterly, 41, 657-680.

Verschueren, J. (1999). Understanding pragmatics. London: Arnold.

Wang, X. Y. (2016). Identity construction of advertisers: from the perspective of historical 


\section{Macrothink}

social pragmatics. Nanjing: Nanjing University Press.

Wang, X. Y., \& Chen, M. (2020). "A little bit out of control”: Doing identity-work by Chinese university teachers in online teachings. Sinologia Hispanica, China Studies Review, 10(1), 97-118.

Woike, J. K., Collard, P., \& Hood, B. (2020). Putting your money where your self is: Connecting dimensions of closeness and theories of personal identity. PLOS ONE, 15(2), 1-44. https://doi.org/10.1371/journal.pone.0228271

$\mathrm{Wu}$, J. (2015). The pragmatic identities and discursive devices of online English teachers. Journal of Guangxi Normal University, 3, 165-171. http://doi.org/10.16088/j.issn.1001-6597.2015.03.028

Wu, J. (2019). Subjectivity of news headlines: from the perspective of pragmatic identity theory. Guangzhou: Jinan University Press.

Xu, M., \& Chen, X. R. (2015). The identity construction of college English teachers and its adaptability in classroom discourse. Foreign Language Education, 36(3), 50-54.

Yuan, Z. M. (2015). A study of identity construction based on the discourse practice of business consultants. Guangzhou: Jinan University Press.

Zhao, J. (2011). Colloquialism: Rhetoric strategy of Russian mass media language. Foreign Language Research, 4, 32-35. http://doi.org/10.16263/j.cnki.23-1071/h.2011.04.019

Zou, M. L. (2020). Research on multi-dimensional teaching mode of computer network course supported by artificial intelligence. University Education, 3, 95-97.

\section{Copyrights}

Copyright for this article is retained by the author(s), with first publication rights granted to the journal.

This is an open-access article distributed under the terms and conditions of the Creative Commons Attribution license (http://creativecommons.org/licenses/by/4.0/) 